\title{
Development of Islanding Preventive Device using Inter-harmonic Current Injection Method for 22, $33 \mathrm{kV}$ Grid Interconnection
}

\author{
Yasuyuki Natsuda Member (Nissin Electric Co., Ltd., R\&D Labs.) \\ Satoshi Uda Member (Nissin Electric Co., Ltd., R\&D Labs.) \\ Shoji Nishimura Member (Nissin Electric Co., Ltd., R\&D Labs.) \\ Fumio Yamamoto Member (The Kansai Electric Power Co., Inc., Energy Use R\&D Labs.) \\ Hiromu Kobayashi Member (Central Research Institute of Electric Power Industry)
}

Keywords: inter-harmonics, distributed generation, grid interconnection, islanding preventive device, and active detection method

This paper describes the development of the new islanding preventive device using interharmonic current injection method for $22 \mathrm{kV}$ or $33 \mathrm{kV}$ electric power system interconnection and the demonstration test results at Akagi Test Center of CRIEPI. The usual islanding preventive device is limited for $6.6 \mathrm{kV}$ electric power system interconnection use, because the impedance of a $22 \mathrm{kV}$ or $33 \mathrm{kV}$ electric power system is too small for the device to detect the islanding phenomena of the $22 \mathrm{kV}$ or $33 \mathrm{kV}$ electric power system. We have developed the new islanding phenomena detection method. These method is composed of the noise elimination technique using digital filter and the small-sized technique using more than one interharmonic.

Frequency of power system reaches a maximum fluctuation of about $0.2 \mathrm{~Hz}$. The fluctuation of frequency causes a noise of measured interhamonics waves. We have made the point at issue clear by using fundamental wave and integer degree harmonics waves elimination filters. Figure 1 shows the effect of digital filtering using DFT(Discrete Fourier Transform) and Comb filters.

We have carried out an experiment on demonstration islanding tests with a real large scale $22 \mathrm{kV}$ test facility at Akagi Test Center of CRIEPI (Fig. 2). As a result, we have made clear that the new islanding detection method is useful and does not malfunction. (Fig. 3)

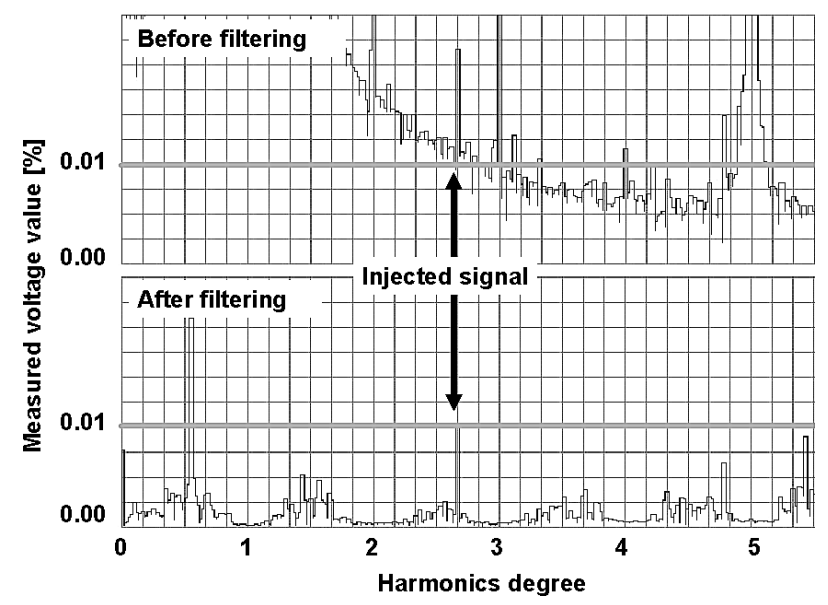

Fig. 1. Effect of filtering

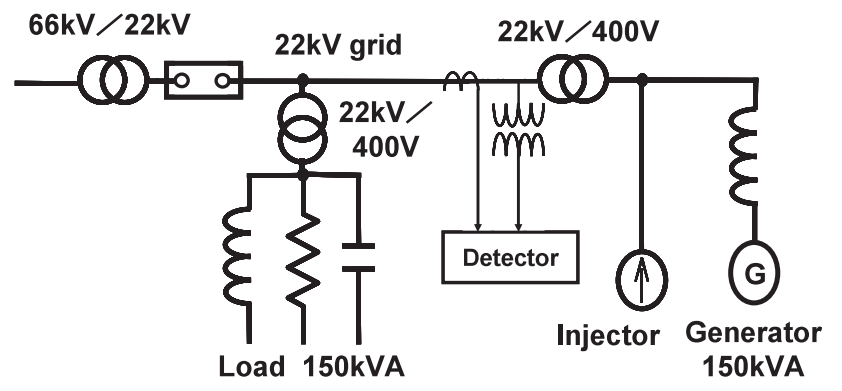

$66 \mathrm{kV} / 22 \mathrm{kV}$ transformer: 2MVA, j14.6\% (at 10MVA base)

Generator: $150 \mathrm{~kW}$ (synchronous machine) $150 \mathrm{~kW}$ (induction machine)

Fig. 2. Testing power circuit

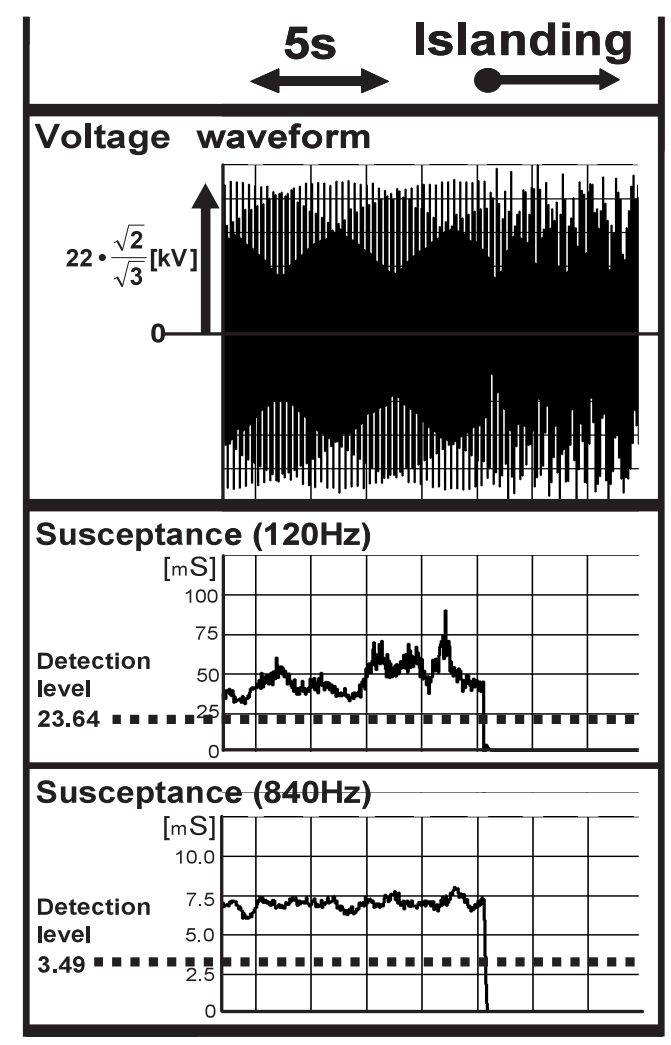

Fig. 3. Oscillograph of voltage wave form and susceptance 


\section{次数間高調波注入による $22,33 \mathrm{kV}$ 用単独運転検出装置の開発}

$\begin{array}{lllll}\text { 正員 夏田 肙千* } & \text { 正員 宇田 怜史* } \\ \text { 正員 西村 荘治* } & \text { 正 員 山本 文雄** } \\ \text { 正員 小林 広武*** } & & & \end{array}$

\section{Development of Islanding Preventive Device using Inter-harmonic Current Injection Method for $22,33 \mathrm{kV}$ Grid Interconnection}

Yasuyuki Natsuda*, Member, Satoshi Uda*, Member, Shoji Nishimura*, Member, Fumio Yamamoto**, Member, Hiromu Kobayashi***, Member

This paper describes the development of the new islanding preventive device using interharmonic current injection method for $22 \mathrm{kV}$ or $33 \mathrm{kV}$ electric power system interconnection and the demonstration test results at Akagi Test Center of CRIEPI. The islanding preventive device using interharmonic current injection method is limited for $6.6 \mathrm{kV}$ electric power system interconnection use, because the impedance of a $22 \mathrm{kV}$ or $33 \mathrm{kV}$ electric power system is too small for the device to detect the islanding phenomena of the $22 \mathrm{kV}$ or $33 \mathrm{kV}$ electric power system. We have developed the new islanding phenomena detection methods. These methods are composed of the noise elimination technique using digital filter and the small-sized technique using more than one interharmonic.

キーワード：次数間高調波，分散電源，系統連系，単独運転検出，能動的方式

Keywords: inter-harmonic, distributed generation, grid interconnection, islanding preventive device, active detection method

\section{1.はじめに}

近年，環境やエネルギーコスト意識の高まりに伴い風力 発電やコジェネレーション等の分散電源が積極的に導入さ れている。分散電源を逆潮流ありで系統に連系する際には, 系統事故等により変電所の送り出し遮断器が開放されたと しても, 分散電源が他の需要家に電力供給を継続する状態 である単独運転状態となる可能性がある。この単独運転状 態は電気保安などの面で問題がある。したがって，系統側 の供給停止時には分散電源側の単独運転を速やかに検出し て, 系統から確実に解列する必要がある。この対策につい ては, 電気設備の技術基準の解釈 ${ }^{(1)} に$, 電力会社の変電所 と分散電源の間に通信線を設置する方式（以下，「転送遮断

\footnotetext{
*日新電機 (株) 技術開発研究所

₹ 615-8686 京都市右京区梅津高畧町 47

R\&D Labs., Nissin Electric Co., Ltd.

47, Umezu-Takase-cho, Ukyo-ku, Kyoto 615-8686

** 関西電力 (株) エネルギー利用技術研究所

干 661-0974 尼崎市若王寺 2-11-20

Energy Use R\&D Labs., The Kansai Electric Power Co., Inc.

3-11-20, Nakoji, Amagasaki 661-0974

*** (財) 電力中央研究所 システム技術研究所

干 201-8511 狛江市岩戸北 2-11-1

Central Research Institute of Electric Power Industry

2-11-1, Iwado, Kita, Komae 201-8511
}

方式」という）と分散電源に単独運転検出装置（能動的方 式を 1 方式以上含むもの）を設置する方式の 2 種類が規定 されており，何れか一方を選ぶようになっている。

転送遮断方式は, 变電所側と分散電源側の双方に送受信 装置および両者の間に専用通信線を必要とするなど, 費用, スペース, 保守運用などの問題がある。また, 既存の単独 運転検出装置についても, 能動的方式については, 有効電 力変動による電圧変動などの電力品質悪化, 複数台設置に より検出感度低下などの課題が挙げられる。そこで，これ らの課題を解決するために, 日新電機と関西電力が非整数 の次数の高調波（以下，「次数間高調波」という）の電流を 系統側に注入して単独運転を検出する方式 (「電気設備の技 術基準の解釈」では「能動的方式」に分類される)，および この方式を装備した分散電源の系統連系保護装置（以下, 単独運転検出装置という）を共同開発し(2)，2005 年度末で 150 セット以上が主に $6.6 \mathrm{kV}$ 系統に連系される分散電源に 用いられている。図 1 に現在用いられている単独運転検出 装置の外観写真を示す。

しかし, 本方式を $22,33 \mathrm{kV}$ 系統に適用する場合は, $6.6 \mathrm{kV}$ 系統の場合に比べ系統インピーダンスが小さいため, より 大きな次数間高調波電流を注入することにより, 当該次数 間高調波成分の電圧および電流の検出感度を確保する必要 があり, その結果, 装置が大型になるか, 適用できないと 


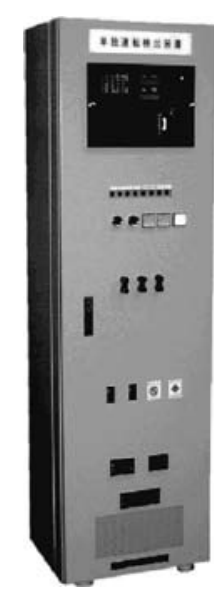

図 1 現在の装置

Fig. 1. Current device.

いう問題点があった。そこで，本論文では，次数間高調波 成分の電圧・電流の検出感度を低下させず，かつ装置の大 型化も回避する新しい方式を提案し，さらに，この新しい 方式に対する実規模系統での検証試験を行ったので，その 結果を述べる。

\section{2. 次数間高調波注入方式の原理と特長 ${ }^{(2)}$}

$\langle\mathbf{2} \cdot \mathbf{1}\rangle$ 次数間高調波の定義 次数間高調波とは, 整 数次数の高調波の間に存在する非整数次数の高調波であり, 具体例としては，整数次数の高調波である第 2 次高調波 と第 3 次高調波の間の第 2.4 次高調波が次数間高調波であ る。言い換えれば，次数間高調波とは，系統周波数よりも 低い周波数を基本波とする整数次数の高調波であり，具体 例としては，基本波周波数を $2 \mathrm{~Hz}$ の場合の第 72 次高調波 $(2 \mathrm{~Hz} \times 72=144 \mathrm{~Hz})$ が，系統周波数 $60 \mathrm{~Hz}$ を基本波にし た場合の第 2.4 次高調波 $(60 \mathrm{~Hz} \times 2.4=144 \mathrm{~Hz})$ に相当 する。

$\langle\mathbf{2} \cdot \mathbf{2}\rangle$ 次数間高調波の特長 通常の電力系統の電圧 には，次数間高調波成分はほとんど含まれていない。図 2 に $22 \mathrm{kV}$ 系統の電圧に対する周波数特性の例を示す。これ によると整数次数，特に奇数の整数次数の高調波成分は存 在するが，次数間の周波数領域にはほとんど高調波は存在 しない。したがって，次数間高調波は，分散電源が接続さ れている系統において次数間高調波電流を微少量注入し, 連系点における注入周波数成分の電圧，電流を計測するた けで，整数次高調波電流を注入する場合に比べて高感度に 分散電源から眺めた系統インピーダンスを監視することが できるという特長を有している。

$\langle\mathbf{2} \cdot \mathbf{3}\rangle$ 次数間高調波成分の計算方法 次数間高調波 成分は, 系統周波数よりも低い周波数の周期 (系統周波数の 周期の整数倍）に対してフーリエ級数展開した各係数に対 して離散的フーリェ変換（DFT）演算手法を用いて求める ことができる。本論文では，式表示を簡素にするため，測 定波形の次数間を含めた高調波成分の検討では，オイラー

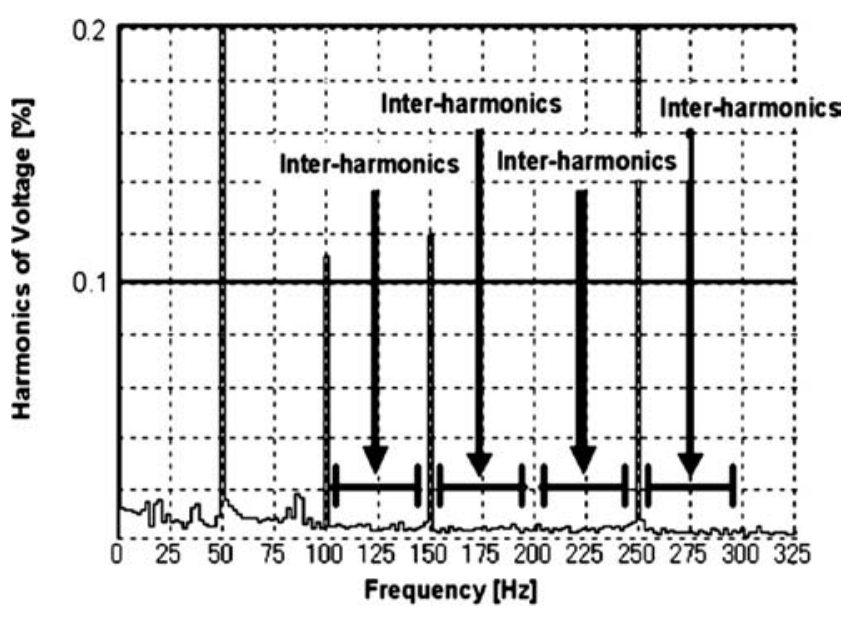

Harmonics at $50 \mathrm{~Hz}$ (frequency of power grid) is $100 \%$.

図 $222 \mathrm{kV}$ 系統の周波数特性

Fig. 2. Example of frequency characteristics of $22 \mathrm{kV}$ electric power system.

の恒等式の複素形式 $\left(e^{j \theta}=\cos \theta+j \sin \theta\right)$ を用いることと し, また, 時間 $(t)$ は次式のとおり系統の標準周波数 $(f s)$ で正規化した值を用いる。

$$
t=2 \pi f_{s} \times \text { 時間 }
$$

フーリエ級数展開をする区間を系統標準周波数の周期の $m$ 倍とすると, 電圧または電流の次数間高調波の $n$ 次係数 $X(n)$ は，電圧または電流の計測データ $x(t)$ を使って， 式により算出される。

$$
\begin{aligned}
X(n) & =\frac{1}{2 \pi} \int_{0}^{2 \pi} x(t) \cdot e^{-j(n \cdot m) \cdot(t / m)} \cdot d\left(\frac{t}{m}\right) \\
& =\frac{1}{2 \pi \cdot m} \int_{0}^{2 \pi \cdot m} x(t) \cdot e^{-j n \cdot t} \cdot d t \ldots \ldots \ldots \ldots
\end{aligned}
$$

(2) 式において，系統の標準周波数の成分は $n=1$, 第 $n$ 次高調波は $n \cdot m=$ 整数の条件で算出される。 $n$ 次と $(n+1)$ 次の間にある算出可能な次数間高調波成分次数は, $n+k / m(k=1,2, \cdots, m-1)$ であり, $(m-1)$ 個の次数 間高調波成分が算出される。すなわち, 系統標準周波数の $m$ 倍の周期に対してフーリエ級数展開をすることにより, 「系統標準周波数（例えば $60 \mathrm{~Hz}) \div m$ (例えば 30)」の周波 数刻み（例えば $2 \mathrm{~Hz}$ ) で次数間高調波成分を算出できるこ とを示している。

今回の開発でも従来の装置と同様に $m=30$ とし, フー リエ級数展開をする区間を $50 \mathrm{~Hz}$ 地域においては 0.6 秒, $60 \mathrm{~Hz}$ 地域においては 0.5 秒とすることにより，1 秒以内で の単独運転検出・解列を実現している。

$\langle\mathbf{2} \cdot \mathbf{4}\rangle$ 単独運転検出方式の原理 本装置の単独運転 検出の原理は, 分散電源の連系点から系統側をみた次数間 高調波成分のインピーダンスまたはアドミタンスを監視す ることにより, 変電所の遮断器の開放, すなわち単独運転 への移行を見つけるものであり，具体的には，分散電源の 連系点から次数間高調波電流を系統側に注入し，連系点に 


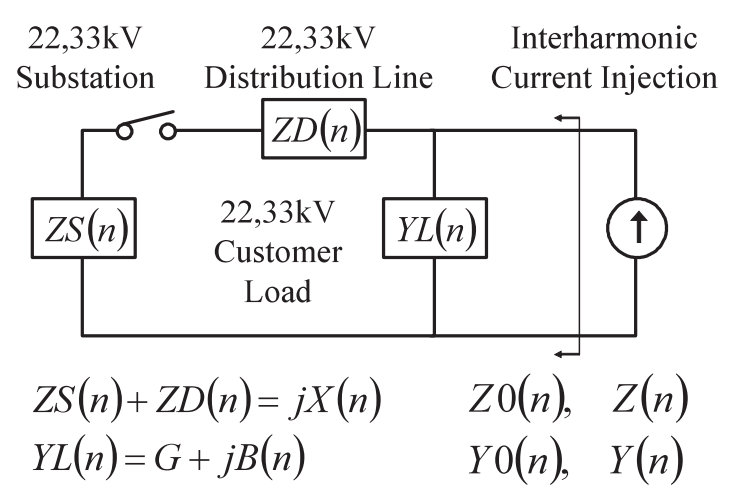

図 $322 \mathrm{kV}$ 系統の単相モデル

Fig. 3. Single phase model of $22 \mathrm{kV}$ electric power system.

おける次数間高調波成分の電圧と電流を計測し，インピー ダンスまたはアドミタンスを計算することにより監視する ものである。

図 3 に次数間高調波成分 (第 $n$ 次) に対する単独運転 発生時の $22 \mathrm{kV}$ 系統の単相モデルを示す。変電所より上 位のインピーダンスを $Z S(n)$, 線路のインピーダンスを $Z D(n)$, 系統負荷のアドミタンスを $Y L(n)$ とする。さらに, 次数間高調波の周波数は電源周波数より大きく, $Z S(n)$ と $Z D(n)$ は抵抗成分に比ベリアクタンス成分が主流になるた め, $Z S(n)+Z D(n)=j X(n)$ と表す。また, 電源周波数での 系統負荷は，コンデンサにより力率改善されるため全体と してはほほ抵抗負荷となるが, 次数間高調波では周波数が 大きいため，系統負荷のアドミタンスは力率改善用コンデ ンサの影響が大きくなるため, $Y L(n)=G+j B(n)$ と表す。 したがって, 単独運転発生前の分散電源の連系点から系統 側をみた次数間高調波成分のインピーダンス拉よびアドミ タンスの值を $Z 0(n)$ 抒よび $Y 0(n)$, 単独運転発生後の值を $Z(n)$ 抢よび $Y(n)$ とすると, これらは次式で示すことがで きる。

$$
\begin{aligned}
& Z 0(n)=\frac{G-j\left\{B(n)-\frac{1}{X(n)}\right\}}{G^{2}+\left\{B(n)-\frac{1}{X(n)}\right\}^{2}} \ldots \ldots \ldots \ldots \ldots \\
& Z(n)=\frac{G-j B(n)}{G^{2}+B^{2}(n)} \\
& Y 0(n)=G+j\left\{B(n)-\frac{1}{X(n)}\right\} \\
& Y(n)=G+j B(n) \cdots
\end{aligned}
$$

上式によると, 単独運転発生の前後で, インピーダンス では実数（抵抗）と虚数（リアクタンス）の両方が変化する のに対し，アドミタンスでは実数 (コンダクタンス) が変 化せず，虚数（サセプタンス）のみが $1 / X(n)$ の変化をする ことになり, サセプタンスの変化で最も感度良く検出でき るため，系統の監視はサセプタンスで行うことにした。一 般的に配電線や变電所のリアクタンス成分は, 負荷のリア
クタンス成分に比べて小さく, 単独運転発生でリアクタン スの大きい負荷のみのとなり, サセプタンスはほとんど零 に変化する。負荷が変電所近傍であったとしても，この変 化に大きな影響はない。しかし，まれなケースとして，配 電線が長く, 配電線のリアクタンスが負荷のリアクタンス に比べて十分小さくなければ, 単独運転前後のサセプタン 又変化が小さく, 負荷の位置に関係なく単独運転検出が困 難になる。次数間高調波注入方式の単独運転検出装置を適 用する際は，系統定数を検討した上で適用可否を決定する ので，このような特殊なケースでは単独運転検出装置は適 用できないことになる。

$\langle\mathbf{2} \cdot \mathbf{5}\rangle$ 方式の特長 次数間高調波注入方式の特長に ついては文献 (2) で詳述しているが，その主な事項の概要 と今回の開発品 $(22,33 \mathrm{kV}$ 用) との関倸は以下の通りである。

(1) 電力品質への影響小 本方式では, 定常的に系 統に存在する量の少ない次数間高調波成分の電流を注入す る方式のため, 注入電流の量を少なく抑えることができ, 今 回の開発では, この注入電流による次数間高調波成分の系 統電圧の歪を電源周波数の電圧に対して $0.01 \%$ 程度に抑え るものである。

（2）複数台設置による相互干渉無 本方式の装置が 変電所の同一変圧器からの系統に複数台設置されても, そ れぞれの装置が系統へ注入する次数間高調波電流の周波数 を異なるものにすれば，それぞれの装置の監視する系統サ セプタンスの周波数が異なるため, 相互干渉を受けること は無い。今回の開発では, 後述するように複数の次数間高 調波電流を注入させるが, 全て異なる周波数を使うため問 題は発生しない。(実証試験例は文献 (8) 参照)

（3）分散電源の種類と容量による適用制約無 分散 電源の次数間高調波でのインピーダンスは，その種類と容 量に関係なく, 系統 (上位系統) のインピーダンスより大き く(アドミタンスの場合は逆), 本装置の適用については, 分散電源の発電機の種類と容量によって制約を受けること はない。今回の開発品は, $22,33 \mathrm{kV}$ 連系の分散電源を対象 にしているが, その場合も上記の適用制約は無い。ただし， 検出に用いるサセプタンス值の整定値は, 系統定数を考慮 して決定しなければならない。

（4）単相注入が可能 次数間高調波電流の注入を単 相で行っても, 電圧と電流の計測を三相分行うことにより, 正相成分のインピーダンスまたはアドミタンスを把握する ことが可能であるため, 注入相を特定しない単相注入が可 能となる。従って, 単相注入にすることにより注入装置の コストダウンが可能となり, また, 注入相を特定する必要 が無いため, 設置工事が容易となる。この点については, 従来の $6.6 \mathrm{kV}$ 連系と今回の $22,33 \mathrm{kV}$ 連系で条件は同じで ある。

\section{3. ディジタルフィルタによるノイズ除去}

〈3・1〉抽出処理方法安定したサセプタンス監視を 行うためには, 注入成分の大きさが, 系統のバックグラウン 
ドノイズに対して，十分に大きい必要がある。6.6 kV 系統 で使用されている現行装置では， $0.1 \%$ 程度の注入成分の電 圧歪が必要である。しかし, $22,33 \mathrm{kV}$ 系統では短絡容量が 10 倍程度大きいため，これに応じて注入量を増やす必要が あり，装置が大型化してしまう。これに対し，0.01\%の電圧 歪でも監視できるように SN 比を高めれば， $6.6 \mathrm{kV}$ 系統の 注入量のままで $22,33 \mathrm{kV}$ 系統に適用できる。系統のバッ クグラウンドノイズは，系統にもともと存在するものと測 定波形の演算処理の過程で発生するものの 2 つがある。前 者については，そのノイズが正規分布に従うガウス型白色 雑音であると仮定すれば測定期間を長くしてデー夕数を増 すことで改善される。しかし今回は $6.6 \mathrm{kV}$ 系統で使用して いる従来装置よりも検出時間を長くすることはできないの で，系統にもともと存在するノイズの除去は行わない。そ こで，今回は後者の測定波形の演算処理の過程で発生する ノイズについて除去対策を行った。

わが国の系統周波数は, 標準周波数に対して $\pm 0.1 \sim 0.2 \mathrm{~Hz}$ 以内に収めることを目標に管理されている(7)。したがって (1) 式におけるフーリエ級数の係数の計算は, 固定した区間 ((1) 式においては $m / f s)$ に対して行っているため, 系統周 波数が変動している条件下では演算処理の過程で次数間高 調波成分にノイズが含まれることになる。

厳密に述べると，系統周波数が $f s$ から $f$ に変動した場 合，実際には，系統標準周波数 $f s$ の周波数成分は存在せ ず， $f s$ を基準として $(f / f s)$ 次成分のみが存在することに なるが，(2) 式で得られる次数間高調波を含む各次数の成 分は，得られる次数が離散的であるため， $(f / f s)$ の值が $n+k / m(k=1,2, \cdots, m-1)$ と完全に一致しない限り，原 理的には系統の周波数分布を求めることはできない。

そこで，強引に(1) 式を使って計算した場合を考察する。 まず，測定波形 $x(\theta)$ は， $f$ のの周波数成分が存在する振 幅 $\mathrm{A}$ の正弦波とし， $(f / f s)=\alpha$ とすると下式となる。

$$
x(t)=A \cdot e^{j \alpha \cdot t}
$$

(7) 式を (2) 式に代入し $n$ 次係数 $X(n)$ を求める。

$$
\begin{aligned}
& X(n)=\frac{A}{2 \pi \cdot m} \int_{0}^{2 \pi \cdot m} e^{j \alpha \cdot t} \cdot e^{-j n \cdot t} \cdot d t \\
& =\frac{A}{2 \pi \cdot m} \cdot \frac{e^{j 2 \pi \cdot m \cdot(\alpha-n)}-1}{j(\alpha-n)} \quad(n \neq \alpha) \\
& =A \quad(n=\alpha) \text {. } \\
& |X(n)|=\frac{A \sqrt{1-\cos \{2 \pi \cdot m \cdot(\alpha-n)\}}}{\sqrt{2} \cdot \pi \cdot m \cdot(\alpha-n)} \quad(n \neq \alpha) \\
& =A \quad(n=\alpha)
\end{aligned}
$$

(9) 式で得られた $n$ 次係数 $X(n)$ の絶対值の特性を, $A=1$, $m=30$ (従来および今回の開発品で採用している值。 $\langle 2 \cdot 3\rangle$ 節参照。）および系統標準周波数 $f s=60 \mathrm{~Hz}$ の条 件で，系統周波数 $f$ を $f s$ から $0.001 \mathrm{~Hz}, 0.01 \mathrm{~Hz}, 0.1 \mathrm{~Hz}$ 変動させた場合を図 4 に示す。これらの系統周波数は，(9) 式で計算される周波数成分が $f s / m=2 \mathrm{~Hz}$ 間隔であること

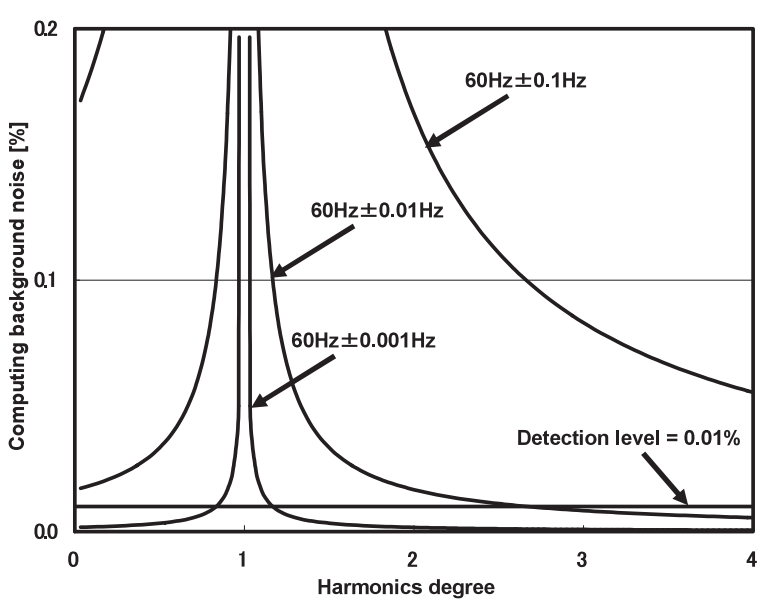

図 4 バックグラウンドノイズの数值シミュレーション

Fig. 4. Computing background noise.

を考慮すると，実際の系統の周波数特性としては全て零で ある。しかし，これによると，系統標準周波数の次数であ る 1 次を中心に裾を引くように次数間高調波成分が発生し ている。以上が，系統周波数の変動している条件下で演算 処理の過程で次数間高調波成分にノイズが含まれる原因で ある。

今回の開発では $0.01 \%$ 電圧歪でも監視できるようにす る必要があるため, 2 から 3 次の間の次数間高調波を採用 する本装置では (2)，0.01 Hz 程度の系統周波数の変動でも監 視すべき信号がこのノイズによって隠れてしまう。

以上述べたように系統周波数が標準周波数からずれるこ とにより演算過程で次数間高調波のノイズが発生するが, 同様に系統に多く含まれる整数次数高調波が標準周波数の 整数倍からずれる場合も演算過程で次数間高調波ノイズが 発生する。

この対策としては，(7) 式の $A$ の值を小さくすること，す なわち測定信号に含まれる基本波 (系統の標準周波数成分) とその整数次高調波を急峻な周波数特性を持つフィルタで 除去することが有効である。アナログフィルタ（ラプラス 変換の伝達関数が $\mathrm{s}$ の有理式で表現されるフィルタ）だけ では急峻な周波数特性と高速な即応性を併せ持った性能の 実現が困難なので，図 5 のようにディジタルフィルタもあ わせて用いることにした。

基本波除去のディジタルフィルタは，離散フーリェ変換 （DFT）で基本波成分を逐次抜き出し演算して，原信号から 減算することにした。また，整数次高調波成分についても， コムフィルタ（節型フィルタ）を用いて，原信号から基本 波の一周期まえの值を減算することにより，除去できる構 成とした。

上記のフィルタについては，シミュレーションを実施す ることにより，定常特性および過渡特性について検討した。 以下にその検討結果について述べる。

〈3・2〉 定常特性 まず，基本波除去フィルタの原理 について述べる。時刻 $t$ における原波形 $b(t)$ の基本波成分 


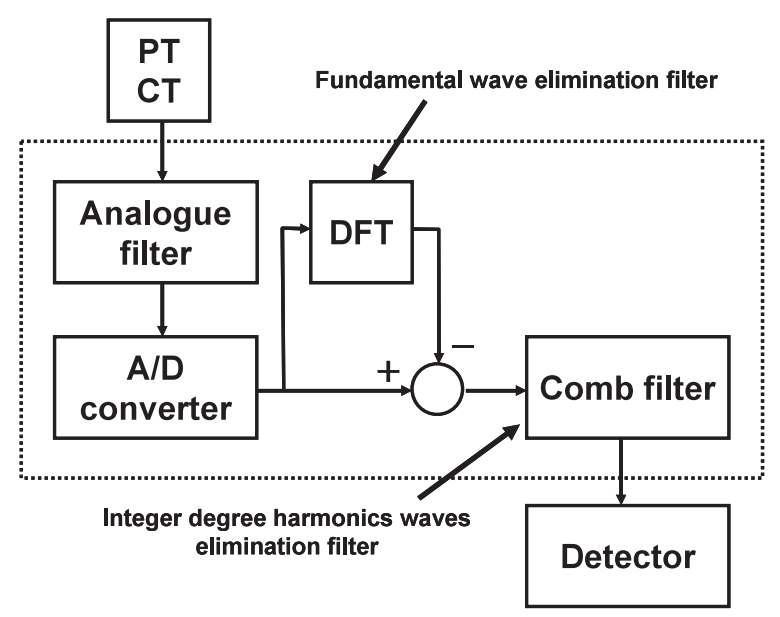

図 5 DFT を用いた抽出処理フィルタ

Fig. 5. Extraction processing DFT filter.

の瞬時值 $c(t)$ は, 過去一周期 $(2 \pi)$ に対する複素フーリエ 係数 $\left(\alpha_{1}-j \beta_{1}\right)$ に複素形式の基本波 $\left(e^{j t}=\cos t+j \sin t\right)$ を乗じ，その実数部 $\left(\alpha_{1} \cos t+\beta_{1} \sin t\right)$ をとることにより 求まる。

$$
\begin{aligned}
c(t)= & \alpha_{1} \cdot \cos t+\beta_{1} \cdot \sin t \\
= & \operatorname{Re}\left\{\left(\alpha_{1}-j \beta_{1}\right) \times(\cos t+j \sin t)\right\} \\
= & \operatorname{Re}\left\{\frac{1}{\pi} \cdot \int_{t-2 \pi}^{t} b(\tau) \cdot e^{-j \tau} \cdot d \tau \times e^{j t}\right\} \\
= & \frac{1}{\pi} \cdot \int_{t-2 \pi}^{t} b(\tau) \cdot \operatorname{Re}\left\{e^{j(t-\tau)}\right\} \cdot d \tau \\
= & \frac{1}{\pi} \cdot \int_{t-2 \pi}^{t} b(\tau) \cdot \cos (t-\tau) \cdot d \tau \\
= & \frac{1}{\pi} \cdot \int_{0}^{t} b(\tau) \cdot \cos (t-\tau) \cdot d \tau \\
& -\frac{1}{\pi} \cdot \int_{0}^{t-2 \pi} b(\tau) \cdot \cos \{(t-2 \pi)-\tau\} \cdot d \tau
\end{aligned}
$$

上式を畳み込み積分であることを考慮してラプラス変換 すると次式となる。

$$
\begin{aligned}
C(s)= & \frac{1}{\pi} \cdot B(s) \cdot \frac{s}{s^{2}+1} \\
& -\frac{1}{\pi} \cdot e^{-2 \pi s} \cdot B(s) \cdot \frac{s}{s^{2}+1} \\
= & \frac{1-e^{-2 \pi s}}{\pi} \cdot \frac{s}{s^{2}+1} \cdot B(s) \cdots
\end{aligned}
$$

基本波除去フィルタの出力波形 $d(t)$ は次式となる。

$$
d(t)=b(t)-c(t)
$$

上式をラプラス変換すると次式となる。

$$
\begin{aligned}
D(s) & =B(s)-C(s) \\
& =\left\{1-\frac{1-e^{-2 \pi s}}{\pi} \cdot \frac{s}{s^{2}+1}\right\} \cdot B(s)
\end{aligned}
$$

したがって基本波除去フィルタの伝達関数 $H_{0}(s)$ は次式
となる。

$$
H_{0}(s)=\frac{D(s)}{B(s)}=1-\frac{1-e^{-2 \pi s}}{\pi} \cdot \frac{s}{s^{2}+1}
$$

基本波除去フィルタの定常状態における周波数特性は, 上式に $s=j n$ ( $n$ : 次数) を代入することにより求まる。

$$
\begin{aligned}
H_{0}(j n) & =1-\frac{1-e^{-j 2 \pi n}}{\pi} \cdot \frac{j n}{-n^{2}+1} \\
& =1-\frac{2}{\pi} \cdot \frac{n}{n^{2}-1} \cdot e^{-j \pi n} \cdot \sin (\pi n) .
\end{aligned}
$$

系統周波数は, 標準周波数 (基本波) に対して最大 $\pm 0.2 \mathrm{~Hz}$ の範囲で変動する可能性があるため, このことも考慮し, 基 本波の除去帯域を広げるため基本波除去フィル夕を 2 段の カスケードで構成した。その結果, 基本波除去フィルタの 総合の伝達関数 $H(s)$ は次式となる。

$$
H(j n)=\left\{1-\frac{2}{\pi} \cdot \frac{n}{n^{2}-1} \cdot e^{-j \pi n} \cdot \sin (\pi n)\right\}^{2} \ldots
$$

次にコムフィルタの原理について述べる。時刻 $t$ におけ るコムフィルタの出力波形を $e(t)$ とすると, 入力波形 $d(t)$ から基本波一周期まえの波形 $d(t-2 \pi)$ を減算することに よって得られるため次式となる。

$$
e(t)=d(t)-d(t-2 \pi)
$$

上式をラプラス変換すると次式となる。

$$
\begin{aligned}
E(s) & =D(s)-e^{-2 \pi s} D(s) \\
& =\left(1-e^{-2 \pi s}\right) \cdot D(s)
\end{aligned}
$$

したがって基本波除去フィルタの伝達関数 $G(s)$ は次式と なる。

$$
G(s)=\frac{E(s)}{D(s)}=1-e^{-2 \pi s}
$$

基本波除去フィルタの定常状態における周波数特性は, 上式に $s=j n$ ( $n$ : 次数) を代入することにより求まる。

$$
G(j n)=1-e^{-j 2 \pi n}
$$

(16) 式と (20) 式で示される基本波除去フィルタ，コム フィルタ, および両者を併用したフィルタの周波数特性を 図 6 に示す。基本波除去フィルタは基本波成分のみを除去 し，コムフィルタは基本波および整数次高調波を除去する 特性を有していることがわかる。基本波除去フィルタは 2 段で使用している関係で，コムフィルタに比べ該当次数だ けでなくその周辺の次数も除去する特性となっている。こ れは, 基本波が整数次高調波に比べ通常十倍以上大きく，か つ基本波の周波数は最大で $\pm 0.2 \mathrm{~Hz}$ 変動する可能性がある ため, 基本波の除去を完全に行うためである。また，両者 を併用したフィルタでは, 整数次付近を除き, 次数間の部 分は増幅される特性になっており, 注入する次数間高調波 信号の検出感度を向上できることを示している。

図 7 に実際の系統に次数間高調波電流を注入したときの 


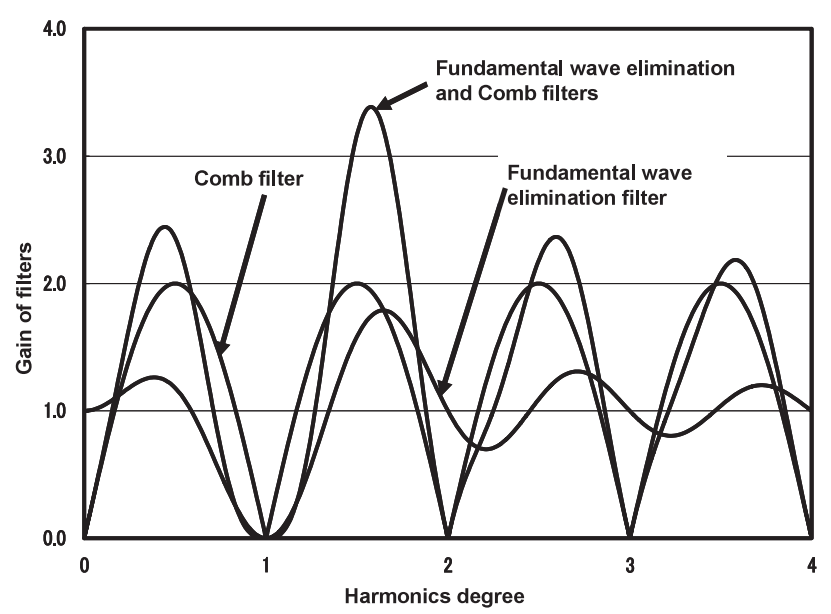

図 6 抽出処理フィルタの周波数特性

Fig. 6. Frequency characteristics of filters.

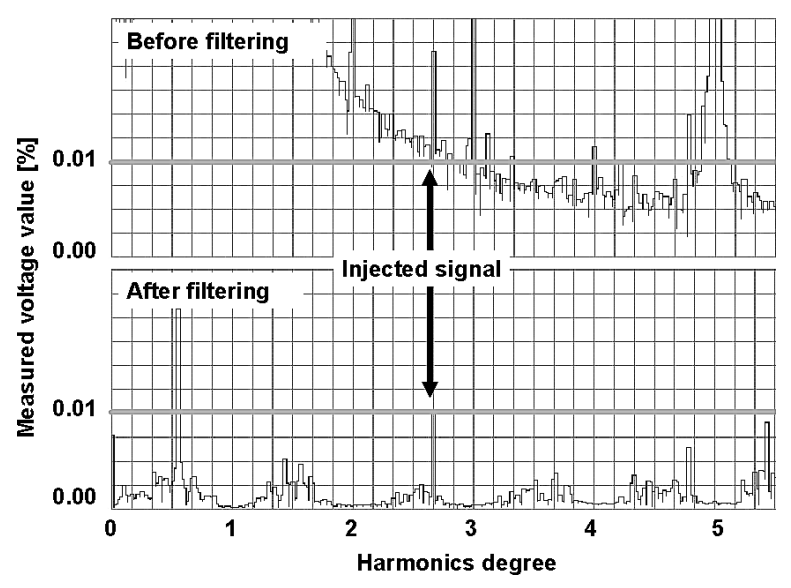

図 7 抽出処理フィルタの効果

Fig. 7. Effect of filtering.

系統電圧の測定データに対して，フィルタを通す前と通し た後の周波数特性を示す。その結果, 基本波から裾引きし ていたノイズが殆ど除去され，整数次の高調波も除かれて いる。系統電圧の $0.01 \%$ 程度の注入次数間高調波成分でも 検出可能となることを示している。

$\langle\mathbf{3} \cdot \mathbf{3}\rangle$ 過渡特性 電力系統における電圧・電流波形に は，短時間で発生する過渡変動（例えば瞬時電圧低下状態， 容量の大きな SC (力率改善用コンデンサ) 投入, 容量の 大きな発電機やモー夕の並列, 解列) が存在する。アナロ グフィルタは，原理的に過去の信号の乱れによる影響が指 数関数的に無くなっていく。したがって，上述のように過 去に非常に大きい波形の乱れがあると，相当時間その影響 がフィル夕出力結果に残留する場合が考えられ，抽出結果 への誤差等の影響が長い時間残留してしまう。これに対し DFT フィル夕は, 計測時点から遡って一定期間の計測デー 夕を演算に使用するので，使用する過去計測データの期間 分を経れば過渡的に発生する電圧・電流変動の影響を無く すことができる。よってアナログフィル夕に対して, 図 8 のように，過去の影響を短時間でリセットすることができ，

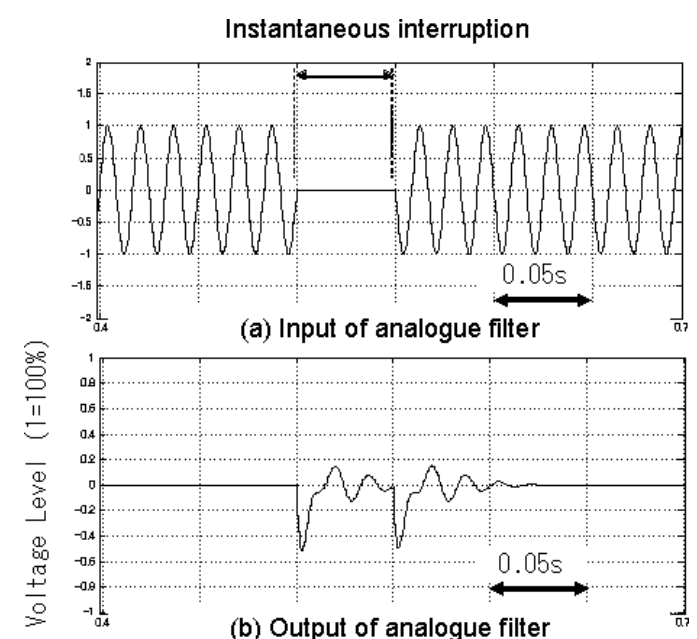

(b) Output of analogue filter

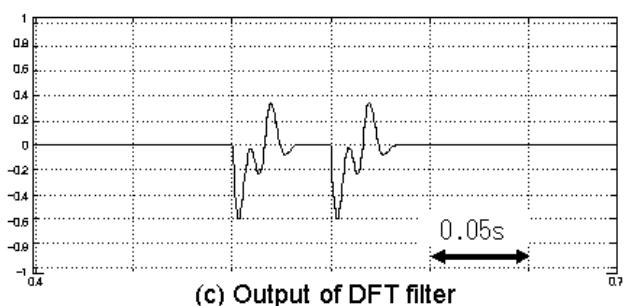

図 8 過渡応答特性

Fig. 8. Transient response characteristics.

即応性に優れているといえる。

\section{4. 複数の次数間高調波注入による大型化回避}

図 9 に次数間高調波電流の注入方法を示す。

まず，直流電圧源をインバータのスイッチングにより $n$ 次の次数間高調波の周波数で变化する方形波電圧源 $v(t)$ を つくる。 $v(t)$ は $n$ 次の周波数の周期関数であるため, $n$ 次の 周波数を基本波としたフーリエ級数展開でき, その結果, $k$ を $n$ 次の次数間高調波電圧 $v(t)$ を基本波とした次数とする と $v(t)$ の $k$ 次成分 $V(k)$ は, $v(t)$ が奇関数であることを考慮 し，次式で表すことができる。

$$
\begin{aligned}
& V(k)=\frac{1}{n \pi} \int_{0}^{2 n \pi} v(t) \cdot \sin (k \cdot n t) \cdot d(n t) \\
& =\frac{4}{\pi k} \quad(k: \text { 奇数 }) \\
& =0 \text { ( } k \text { : 偶数 }) .
\end{aligned}
$$

図 10 に $v(t)$ のピーク值を 1 で正規化した $V(k)$ の特性を 示す。すなわち，方形波に含まれる周波数成分の值は，そ の基本波成分（ $k=1$ の場合）が最も大きく，周波数（ $k$ の 值）に逆比例して小さくなる。

そして，この電圧源 $v(t)$ を，リアクタンス $L$ とコンデン サ $C$ が直列接続された $L C$ 共振回路を通して系統に接続す ることにより, 系統側へ次数間高調波電流 $i(t)$ を注入する ものである。

現行装置では, この $L C$ 共振回路の共振周波数を $n$ 次の 次数間高調波の周波数にすることで, 系統側へは $n$ 次の次 数間高調波の正弦波電流のみを注入している(2)。ここで, $\mathrm{n}$ 

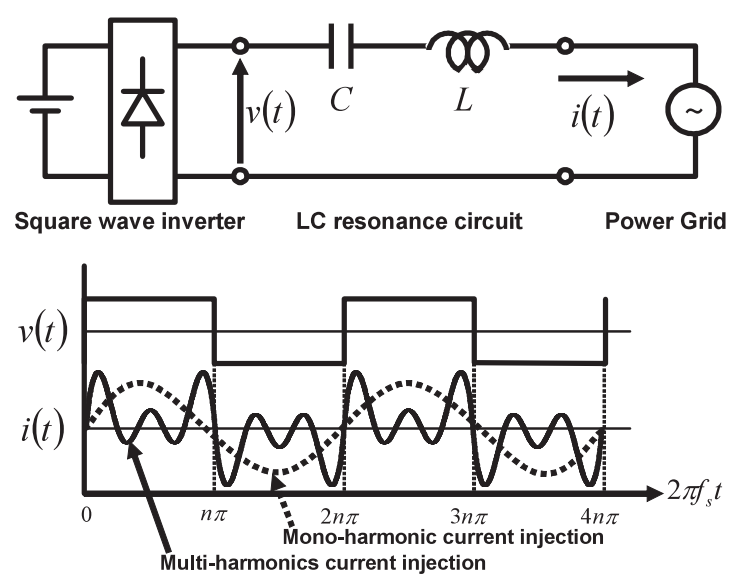

$f_{s}$ : Standard frequency of power grid

図 9 次数間高調波電流の注入方法

Fig. 9. Injected circuit configuration of inverter.
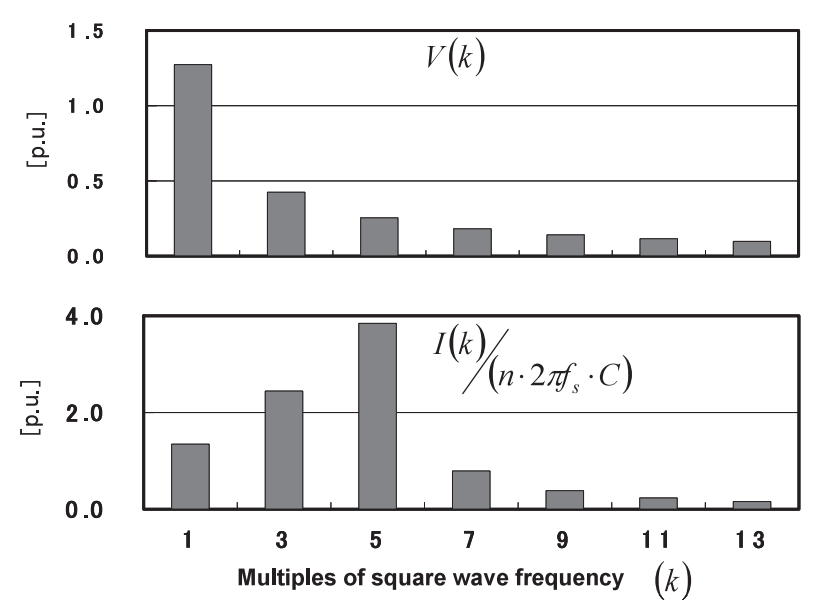

図 10 注入電圧と電流の周波数特性

Fig. 10. Frequency characteristics of injected voltage and current.

の值は, フリッカ周波数領域 (0.5 1.5 次), リアクトル付 き力率改善用コンデンサの直列共振周波数 (4.1 次付近), リアクトル無し進相コンデンサと系統リアクタンス成分と の並列共振周波数 (4.2 次付近) などを避けるために, 2 次 から 3 次の間の次数を採用している(2)。この方法の利点は, スイッチング周波数が数 $\mathrm{kHz}$ の PWM インバータを使った 次数間高調波電源に比ベ，スイッチング周波数が商用周波 数の $n$ 倍と小さいため, スイッチング回数を抑えることが でき，スイッチングロスが小さい点である。しかし， $L C$ 共 振回路の $L$ の值を大きくとる必要があり， $L$ を実現する装 置（リアクトル）が大型になる欠点があった。

そこで今回この大型化を回避するため, リアクトルの鉄 心を空心にし，また巻き線も短くすることにより， $L$ の值 を小さくし， $L C$ 共振回路の共振周波数を高くした。その 結果, 系統側へ注入される次数間高調波電流は, $n$ 次に加 え周波数の高い複数の $n$ 次の整数倍の次数 $(n \times k$ 次 $(k$ : 奇数)）も有する非正弦波電流である。この方法の他の利点 は，バックグラウンドノイズの少ない高周波領域の次数間
高調波での系統監視を可能にする点である。また，リアク トルの巻き線を短くすることで巻き線損失の低減も可能で ある。な㧍，前述した 4 次付近での問題点に対しては， 4 次付近でない複数の次数間高調波を使った監視を行うこと により回避できる。

図 9 に, 方形波インバー夕の周波数が $150 \mathrm{~Hz} \quad(n=2.5)$ における注入電流を, LC 共振回路の共振周波数が $150 \mathrm{~Hz}$ の場合 (単一の次数間高調波成分が含まれた注入電流), お よび $650 \mathrm{~Hz}$ の場合（複数の次数間高調波成分が含まれた

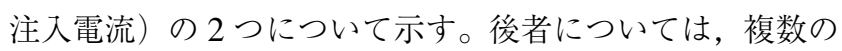
次数が含まれているため, その波形は正弦波ではない。 $i(t)$ に含まれる $n$ 次の $k$ 倍の周波数成分 $I(k)$ は, 交流理論によ り次式で表せる。

$$
\begin{aligned}
& I(k)=\frac{V(k)}{k \cdot n \cdot 2 \pi f_{s} \cdot L-\frac{1}{k \cdot n \cdot 2 \pi f_{s} \cdot C}} \\
& =\frac{4}{\pi} \cdot \frac{n \cdot 2 \pi f_{s} \cdot C}{k^{2} \cdot m^{2}-1} \quad(k: \text { 奇数 }) \\
& =0 \quad(k \text { : 偶数 })
\end{aligned}
$$

$m=\frac{n \cdot f_{s}}{f_{L C}} \quad\left(f_{L C}: L C\right.$ 共振周波数 $)$

$$
i(t)=\sum_{k=1}^{\infty} I(k) \cdot \sin \left\{k \cdot\left(n \cdot 2 \pi f_{s} \cdot t\right)\right\}
$$

この電流波形の周波数特性を図 10 に示す。方形波の電 圧源 $v(t)$ の周波数成分 $V(k)$ は, 周波数が高くなるほど小さ くなるが, 注入電流 $i(t)$ の周波数成分 $I(k)$ は, $L C$ 共振回 路の共振周波数 $(\mathrm{k}=650 \mathrm{~Hz} / 150 \mathrm{~Hz} \fallingdotseq 4.3)$ 付近までは増 加しており, この増加している複数の次数間高調波を使え ることを示している。

\section{5. 実規模での模擬系統試験}

$\langle\mathbf{5} \cdot \mathbf{1}\rangle$ 試験条件 電力中央研究所赤城試験センター の需要地系統実験設備を使用した（図 11）。設備の概要は 以下の通りである。

試験では，単独運転の発生を容易にするため発電電力と 負荷をバランスさせた。次数間高調波電流の注入は分散電 源発電機の低圧側より行い, 電圧・電流計測（監視取り込 み) は $22 \mathrm{kV}$ 側で行った。注入次数間高調波に上る電圧歪 は単独運転前の $22 \mathrm{kV}$ 側に扔いて $0.01 \%$ 程度である。

$\langle\mathbf{5} \cdot 2\rangle$ 試験結果例：条件 A 試験条件 A では, 同一 送電線上に接続されている負荷（分散電源の設置構内以外 の）として, 誘導電動機が支配的な状態を設定した。図 12 に, $22 \mathrm{kV}$ 系統に扔ける単独運転発生時前後の次数間高調波 $(120 \mathrm{~Hz} / 2.4$ 次, $360 \mathrm{~Hz} / 2.4 \times 3=7.2$ 次, $840 \mathrm{~Hz} / 2.4 \times 7=$ 16.8 次) 拈よび高次高調波 (参考: $600 \mathrm{~Hz} / 2.4 \times 5=12$ 次) のサセプタンスの変化を, 表 1 に計算值と実測值を示す。 単独運転が長く継続する条件であるが, いずれの周波数も サセプタンスの変化が安定し, 検出閾值の設定が可能であ り，単独運転検出が可能であることが確認できた。 


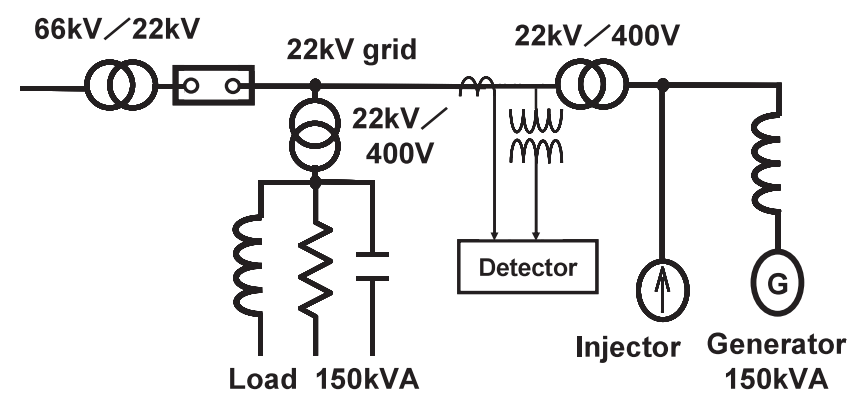

表 1 条件 A でのサセプタンスの計算值と 実測值 [ms]

Table 1. Calculated and measured susceptance values [ms] on the condition-A.

\begin{tabular}{|c|c|c|c|c|}
\hline \multirow{2}{*}{ Condition } & \multicolumn{2}{|c|}{$120 \mathrm{~Hz}(2.4$ degree at $50 \mathrm{~Hz})$} & \multicolumn{2}{c|}{$840 \mathrm{~Hz}(16.8$ degree at $50 \mathrm{~Hz})$} \\
\cline { 2 - 5 } & Calculation & Measurement & Calculation & Measurement \\
\hline Connecting & -49.410 & -46.875 & -7.060 & -6.750 \\
\hline Islanding & -0.516 & -0.395 & -0.074 & -0.220 \\
\hline
\end{tabular}

$66 \mathrm{kV} / 22 \mathrm{kV}$ transformer: 2MVA, j14.6\% (at 10MVA base)

Generator: $150 \mathrm{~kW}$ (synchronous machine)

$150 \mathrm{~kW}$ (induction machine)

困 11 試験系統図

Fig. 11. Testing power circuit.

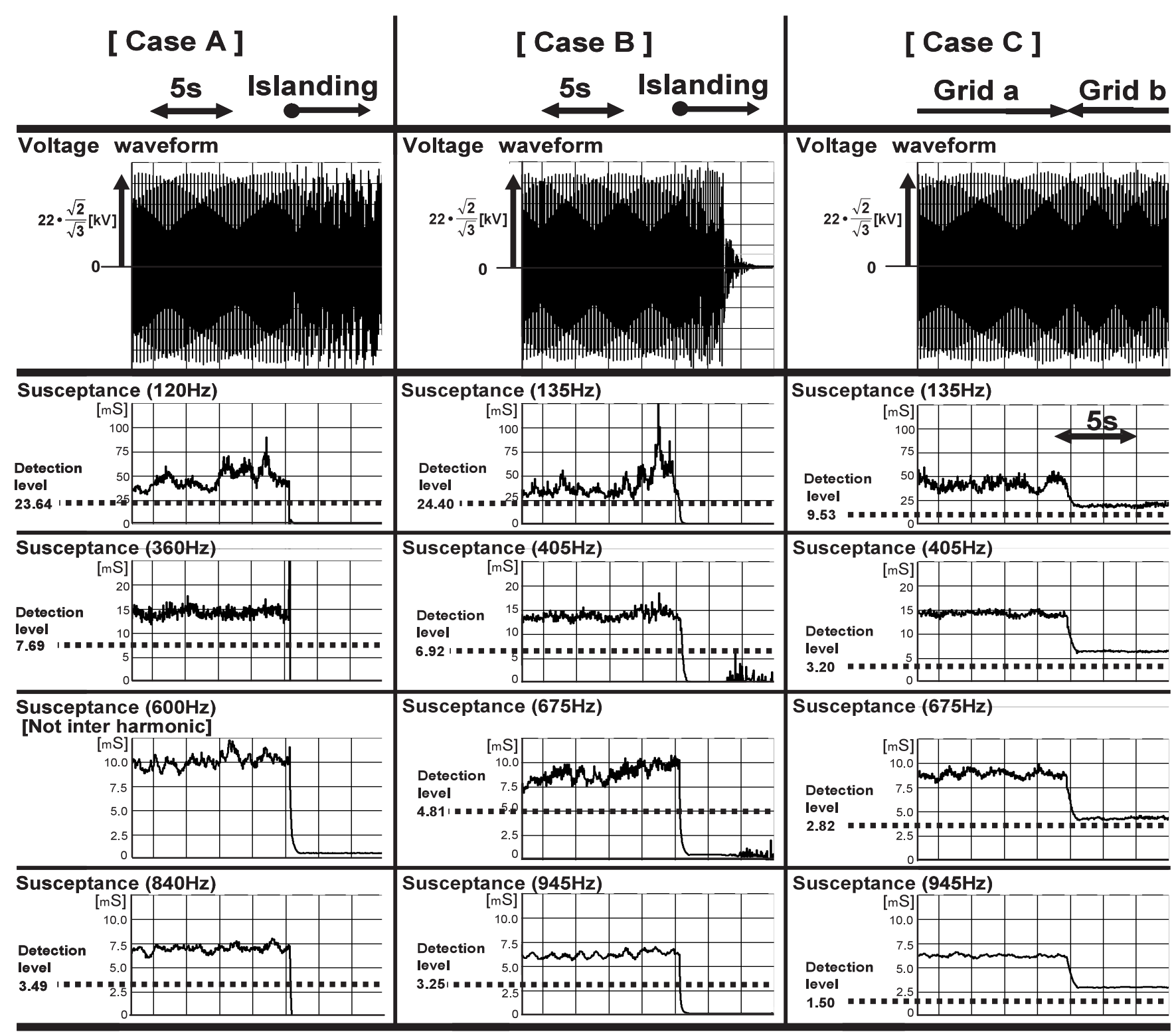

図 12 電圧波形とサセプタンスの時間変化

Fig. 12. Oscillograph of voltage wave form and susceptance. 
なお，この試験ケースでは, $600 \mathrm{~Hz}$ は整数次高調波と周波 数が一致してしまうため, 判定には使用しない設定とした。

$\langle\mathbf{5} \cdot \mathbf{3}\rangle$ 試験結果例：条件 B 試験条件 B では, 同一送 電線上に接続されている負荷として，誘導電動機 50\%，抵 抗負荷 50\%の状態を設定した。図 12 に結果を示す。この ケースでは，単独運転が長くは継続していないが，電圧が 維持されている期間は，サセプタンスの変化が安定し，検 出閾值（判定レベル＝整定值）の設定が可能であり，単独 運転直後に即座に検出が可能であることが確認できた。

$\langle\mathbf{5} \cdot \mathbf{4}\rangle$ 試験結果例：条件 C 試験条件 Cでは，単独 運転状態を発生させることなく，配電線を切り替えた前後 の状態を監視した。図 12 の結果によると, 配電線切り替え 前後のサセプタンスの変化量は, 単独運転発生時の変化量 に比べ小さいことが分かる。従って, 単独運転検出のため のサセプタンスの監視整定值を, 配電線切り替え時のサセ プタンス変化範囲（シミュレーションによる事前計算）に 含まれないように設定しておくことにより，配電線切り替 えによる誤検出を防止できることが確認できた。

\section{6. おわりに}

本論文では, 次数間高調波注入方式の単独運転検出装置を $6.6 \mathrm{kV}$ 系統に比べ系統インピーダンスの小さい $22,33 \mathrm{kV}$ 系統に適用する場合の課題である電圧・電流の検出感度の 低下および注入装置の大型化を回避する新しい方式を提案 し, この新しい方式に対する実規模系統での検証試験を行っ た。その結果をまとめると次のようになる。

(1) 系統の標準周波数は最大 $0.2 \mathrm{~Hz}$ 程度変動する可能 性があるが，この変動に起因する測定波形の演算処理の過 程で発生する次数間高調波成分のバックグラウンドノイズ に対しては，事前にDFTで基本波成分を除去し，さらにコ ムフィルタで整数次数の高調波成分を除去することで解決 できることを明らかにした。

（2）注入装置の大型化の課題に対しては，その装置を 構成するリアクトルの鉄心を空心にし，また巻き線の長さ も短くすることにより $L$ の值を小さくし， $L C$ 共振回路の 共振周波数を高くした。その結果, 注入電流は, 従来より も高い周波数成分を含めた複数の次数間高調波成分で構成 され，バックグラウンドノイズの少ない高周波領域の次数 間高調波での系統監視を可能にした。

(3) 上記の新しい方式に対して, 実規模の $22 \mathrm{kV}$ 系統 において単独運転を発生させて検証を行った結果，単独運 転検出ができることを検証するとともに，配電線切り替え においては誤動作しないことを確認した。

今後は，本方式の製品化をするとともに，検出時間の短 縮化についても検討を進める予定である。

(平成 18 年 7 月 21 日受付，平成 18 年 12 月 1 日再受付)

$$
\text { 文献 }
$$

（1）原子力安全·保安院電力安全課：電気設備の技術基準の解釈 (2004-10.1)
(一部改正)

(2) F. Yamamoto, S. Nishimura, Y. Minowa, and Y. Natsuda: "An Advanced Islanding Detection Device for Dispersed Power Sources using Interharmonic Current", J. IEIE Japan, Vol.24, No.12, pp.943(57)-952(66) (2004-12) (in Japanese)

山本文雄・西村荘治・蒿輪義文・夏田育千：「次数間高調波注入によ る単独運転検出装置の開発」, 電気設備学誌, 24, 12, pp.943(57)-952(66) (2004-12)

(3) Y. Natsuda, S. Nishimura, and F. Yamamoto: "Advanced Islanding Protection Method with Pulsed Injection Current for Dispersed Power Sources", Proc. of 2004 Annual Conference of Power \& Energy Society, IEE Japan, No.413, pp.451-452 (2004-8) (in Japanese)

夏田育千・西村荘治・山本文雄：「パルス注入を用いた次数間高調 波注入による単独運転検出方式」, 平成 16 年電気学会電力・エネル ギー部門大会, No.413, pp.451-452 (2004-8)

(4) Y. Natsuda, S. Nishimura, and F. Yamamoto: "Advanced Islanding Protection Method using Interharmonic Injection for Dispersed Power Sources Interconnecting with 22-77 kV Power System", 2005 National Convention Record IEE Japan, No.6-010, pp.16-17 (2005-3) (in Japanese)

夏田育千 ·西村荘治・山本文雄 :「次数間高調波注入による特別高圧 用単独運転検出方式の開発」, 平成 17 年電気学会全国大会, No.6-010, pp.16-17 (2005-3)

(5) Y. Natsuda, S. Nishimura, F. Yamamoto, and H. Kobayashi: "Test Results of Advanced Islanding Preventive Method using Interharmonics Current", Proc. of 2005 Annual Conference of Power \& Energy Society, IEE Japan, No.173 (2005-8) (in Japanese)

夏田育千・西村荘治・ 山本文雄 - 小林広武 :「次数間高調波注入によ る特別高圧用単独運転検出装置の検証試験結果」, 平成 17 年電気学 会電力・エネルギー部門大会, No.173 (2005-8)

(6) Y. Natsuda, S. Uda, S. Nishimura, F. Yamamoto, and H. Kobayashi: "Development of Islanding Preventive Device using Interharmonic Current Injection Method", The Paper of Joint Technical Meeting on Power Engineering and Power Systems Engineering, IEE Japan, PE-05-127, PSE-05-134 (2005-9) (in Japanese)

夏田育千 ·宇田怜史 ·西村荘治 · 山本文雄 - 小林広武 :「次数間高調 波注入による $22,33 \mathrm{kV}$ 用単独運転検出装置の開発」, 電気学会電力 技術電力系統技術合同研資, PE-05-127, PSE-05-134 (2005-9)

（7）電気学会：新版電気工学ハンドブック,p.883 (1988-2)

(8) M. Okamoto, S. Nishimura, Y. Minowa, and T. Shikata: "Development of Voltage Fluctuation Compensator having a function to prevent Islanding of a Grid-connected Wind Energy Conversion System Part 2-Islanding Operation Detection System for Dispersed Power Sources using Interharmonics Injection-", Proc. of 2000 Annual Conference of Power \& Energy Society, IEE Japan, No.216 (2000-8) (in Japanese)

岡本光明・西村荘治・蓑輪義文・志方俊彦:「系統連系保護機能付き 電力変動補償装置の開発〔その 2] 次数間高調波注入方式単独運 転検出装置について〜」, 平成 12 年電気学会電力・エネルギー部門 大会, No.216 (2000-8)

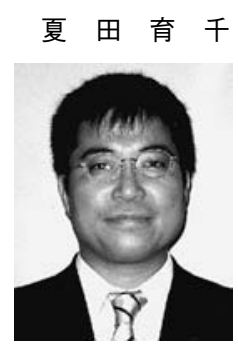

（正員） 1967 年 7 月 10 日生。1992 年 3 月徳島 大学工学部電気工学科卒業。同年 4 月日新電機 (株) 入社。現在, 技術開発研究所システム研究セ ンター主任。主として, 太陽光発電システム, 分 散電源の単独運転検出装置の開発・設計に従事。 2004 年涉澤賞受賞。

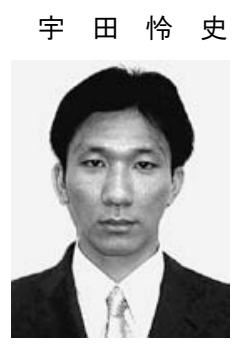

(正員) 1979 年 9 月 16 日生。 2004 年 3 月武蔵 工業大学大学院工学研究科電気工学専攻修士課程 修了。同年 4 月日新電機（株）入社。現在，技術 開発研究所システム研究センターに所属。主とし て, 分散電源の単独運転検出装置の開発・設計に 従事。 
西 村 荘 治 （正員） 1950 年 12 月 16 日生。1 1974 年 3 月名古 屋大学工学部電気工学科卒業。同年 4 月日新電機 (株) 入社。現在，技術開発研究所システム研究七 ンター主幹。主として，電力系統の高調波計測, 分散電源の単独運転検出装置の開発に従事。1998 年オーム技術賞, 2004 年涉澤賞受賞。

山本文 雄

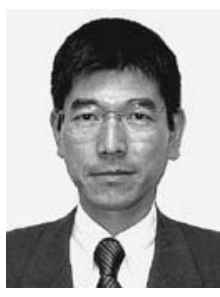

（正員） 1957 年 7 月 10 日生。1982 年 3 月神戸 大学大学院工学研究科電気工学専攻修士課程修 了。同年 4 月関西電力 (株) 入社。現在, エネル ギー利用技術研究所総合エネルギー研究室主任研 究員。主として, 分散電源の系統連系技術, 新工 ネルギーの研究に従事。工学博士。2004 年澁澤 賞受賞。電気設備学会会員。
小 林 広 武 (正員) 1956 年 12 月 28 日生。1982 年 3 月北海 道大学大学院工学研究科電子工学専攻修士課程修 了。同年 4 月電力中央研究所入所。現在, システ 厶技術研究所需要家システム領域上席研究員。主 として, 太陽光発電システム, 需要地系統の研究 に従事。工学博士。1993 年オーム技術賞, 1994 年電気学術振興賞進歩賞, 1997 年同論文賞受賞。 太陽エネルギー学会会員。 